\title{
From Hong Kong Policy Act of 1992 to Hong Kong Human Rights and Democracy Act of 2019: The Evolution of the US's Hong Kong Policy in the Context of the Rise of China
}

\author{
Jie Liu* \& Congyan Cai**
}

The US has huge interests in Hong Kong. In 1992, a few years before China resumed its sovereignty over Hong Kong in 1997, the US adopted the U.S.-Hong Kong Policy Act of 1992. The keynote of the Act is to enhance the cooperation with and maintain the treatment to Hong Kong. This tune has changed in the Hong Kong Human Rights and Democracy Act of 2019, which is obviously the response of the US to widespread protests in Hong Kong arising from the Extradition Bill proposed by the Government of Hong Kong SAR. The new law includes several negative elements. It marks a change in the US policy towards Hong Kong and furthermore represents a change in the US policy towards China. The new law should not merely be understood as the US's support for democracy and human rights in Hong Kong. Instead, it should be considered as a major leverage which the US may maneuver to engage a rising China.

\section{Keywords}

Hong Kong Policy Act, Hong Kong Human Rights and Democracy Act, the US's China Policy, Rise of China

* Ph.D. candidate in international law at Xiamen University School of Law. A.B. (Xiamen)/LL.M.(Nanjing). ORCID: https:/orcid.org/0000-0003-3480-5387. The author may be contacted at: liujie0086@foxmail.com/Address: School of Law at Xiamen University, Xiamen, Fujian, P.R. China, 361000.

** Professor at Fudan University School of Law; Honorary Professor at East China University of Political Science and Law (ECUPL). A.B./LL.M./Ph.D. (Xiamen). ORCID: http://orcid.org/0000-0001-5282-013X. The author may be contacted at: caicongyan@sina.com/Address: 2005, Song hu Road, Fudan University Law School, Shanghai, P.R. China. 


\section{Introduction}

On November 27, 2019, US President Donald J. Trump signed the Hong Kong Human Rights and Democracy Act of 2019 (hereinafter Hong Kong Democracy Act 2019). ${ }^{1}$ In his Presidential Statement, Trump announced that the Hong Kong Democracy Act 2019 "reaffirms and amends the United States-Hong Kong Policy Act of 1992 (hereinafter Hong Kong Act 1992); specifies the US policy towards Hong Kong; and directs the assessment of political developments in Hong Kong." "This action, along with previous preparations for the Act in the Congress, drew fierce condemnation from the Chinese government. For instance, the spokesperson of Chinese Ministry of Foreign Affairs ("MFA") criticized that the US action "is a severe interference in Hong Kong affairs, which are China's internal affairs. It is also in serious violation of international law and basic norms governing international relations." 3 The Government of Hong Kong SAR also expressed strong opposition, stating that "the new law is unnecessary and unwarranted, and will harm the relations and common interests between Hong Kong and the US."

Whether the Hong Kong Democracy Act 2019 can change the US's China policy regarding Hong Kong remains to be seen. However, this Act is different from the US laws regarding Tibet and Xinjiang which were also strongly opposed by China, ${ }^{5}$ because it precisely targets Hong Kong which has been a 'window' for China's integration into globalization as well as a bridgehead for the Anglo-American strategic and economic interests in China. ${ }^{6}$ Arguably, the potential negative impact

1 All the websites cited in this article were last visited on May 7, 2020. Statement of President, Office of the President (Nov. 27, 2019), available at https://www.whitehouse.gov/briefings-statements/statement-by-the-president-30.

2 Id.

3 G. Shuang (Foreign Ministry Spokesperson), Regular Press Conference, PRC Ministry of Foreign Affairs (Nov. 28, 2019), available at https://www.fmprc.gov.cn/mfa_eng/xwfw_665399/s2510_665401/2511_665403/t1719976.shtml.

4 HKSAR strongly objects to acts on Hong Kong becoming US law, Press Release (Nov. 28, 2019), available at https:// www.info.gov.hk/gia/general/201911/28/P2019112800260.htm.

5 For instance, on Dec. 19, 2018, President signed the Reciprocal Access to Tibet Act of 2018, publishing Chinese officials who resisted access to Tibet. See President Donald J. Trump Signs H.R. 1872, H.R. 2454, H.R. 3996 and H.R. 4111 into Law, The White House (Dec. 19, 2018), available at https://www.whitehouse.gov/briefings-statements/ president-donald-j-trump-signs-h-r-1872-h-r-2454-h-r-3996-h-r-4111-law.

6 In July 1996, Winston Lord, then Assistant Secretary for East Asian and Pacific Affairs, stated that "Hong Kong is an international city. Its future stability and continued prosperity are important-not just to China, but to the entire world community, including the United States." See W. Lord, Hong Kong's Progress toward Reversion: Implications for the U.S., 7 Department of State Dispatch 378-80 (1996). China also acknowledges that the US has "important interests." See also G. Shuang (Foreign Ministry Spokesperson), Remarks on the Passage of the Hong Kong Human Rights and Democracy Act in the US House of Representatives, PRC Ministry of Foreign Affairs (Oct. 16, 2019), available at https://www.fmprc.gov.cn/mfa_eng/xwfw_665399/s2510_665401/2535_665405/t1708170.shtml; K. Dumbaugh, The 
of the Hong Kong Democracy Act 2019 should be taken seriously. This Act should not be merely understood as the US's strong support for political protection arising from Hong Kong Extradition Bill proposed in the early 2019. Instead, it should be further considered as a major leverage for the US to engage a rising China. Actually, China has explicitly stated that the Hong Kong Democracy Act 2019 is crafted with an illegitimate aim to "contain China's development."7

The primary purpose of this research is to critically examine the US legislations regarding Hong Kong since 1992. This positive analysis and interpretation will be a firm basis for understanding the US policy towards China under Trump administration and its future. This paper is composed of four parts including Introduction and Conclusion. Part two will review the Hong Kong Act 1992 and Part three will analyze the Hong Kong Democracy Act 2019.

\section{United States-Hong Kong Policy Act of 1992}

\section{A. Background}

On December 19, 1984, China and the UK signed the Joint Declaration on the Question of Hong Kong (hereinafter Joint Declaration 1984). ${ }^{8}$ According to the Declaration, the UK returned Hong Kong to the People's Republic of China on July 1, 1997. ' China, in the Joint Declaration 1984, declared its Hong Kong policy of "One Country, Two Systems." This mainly includes: (a) China will establish Hong Kong Special Administrative Region ("SAR") with "a high degree of autonomy, except in foreign and defense affairs"; (b) the SAR will be vested with "executive, legislative and independent judicial power, including that of final adjudication" and, especially, the chief executive of the SAR will be appointed by the Central Government "on the basis of the results of elections or consultations to be held locally"; (c) the current social and economic systems and lift-style in Hong Kong will remain unchanged. Rights and freedoms, including those of the person, speech, press, assembly, association, travel, movement, correspondence, strike, choice of occupation, academic

U.S. Role During and After Hong Kong's Transition, 18 U. PA. J. InT'L Econ. L. 333 (1997).

$7 \quad I d$.

8 Joint Declaration of the Government of the United Kingdom of Great Britain and Northern Ireland and the Government of People's Republic of China on the Question of Hong Kong (2005), available at https:/www.cmab.gov.hk/en/issues/ jd2.htm.

9 Joint Declaration 1984, art.2. 
research and religious belief will be ensured by law in the SAR; (d) the SAR will retain the status of a free port and a separate customs territory; (e) the SAR will retain the status as an international financial center, and its markets for foreign exchange, gold, securities and futures will continue; (f) the SAR may, in the name of "Hong Kong, China," maintain and develop economic and cultural relations and conclude relevant agreements with states, regions and relevant international organizations on its own; and (g) the SAR Government will be responsible for the public order in the SAR. ${ }^{10}$ In order to formulate the legal framework for Hong Kong before and after its return to China, China's National People's Congress ("NPC") approved the Basic Law of the Hong Kong Special Administrative Region of the People's Republic of China (hereinafter Hong Kong Basic Law 1990) on April 4, 1990, which took into effect on July 1, 1997. ${ }^{11}$

Although several initiatives were proposed by the Congress to support the "selfdetermination" of Hong Kong people, ${ }^{12}$ generally speaking, the US allegedly assumed a low profile in Hong Kong affairs, including Sino-UK negotiations on the Hong Kong's return, throughout the 1980s. This is because the US was not a party of these negotiations and the transfer of Hong Kong to China took a long time. ${ }^{13}$ However, the US deemed it necessary to frame an official legal and external policy towards Hong Kong, given the Tiananmen Square incident and Hong Kong's imminent return to China. Several initiatives were introduced in the US Congress to press China to honor its commitments in the Joint Declaration 1984, especially on human rights, but most of them failed. The US Congress successfully incorporated Hong Kong provisions into two appropriations acts, such as the 1990-1991 Foreign Relations Authorization Act, which did not include enforceable legal arrangements but merely urged the President to stress to the UK the necessity of free and fair election in Hong Kong and

10 Joint Declaration 1984, art. 3 \& annex I (Elaboration by the government of the People's Republic of China of its basic policies regarding Hong Kong).

11 The Basic Law of the Hong Kong Special Administrative Region of the People's Republic of China, 3rd Session of the 7th National People's Congress of the People's Republic of China (Apr. 4, 1990), available at https://www.basiclaw. gov.hk/en/basiclawtext/images/basiclaw_full_text_en.pdf.

12 E.g., H. Con. Res. 299-A concurrent resolution supporting self-determination for the people of Hong Kong, expressing the sense of the Congress that the right of the people of Hong Kong to self-determination should be respected, and that no new government should be imposed on Hong Kong absent the consent of the citizens. See also H. Con. Res. 29998th Congress (1983-1984), available at http://www.congress.gov/bill/98th-congress/house-concurrent-resolution/299; H. Con. Res. 393-A concurrent resolution in support of democracy in Hong Kong, urging the British Government to ensure that the 1991 elections to the Legislative Council involve all members of such Council or a higher proportion than the ten currently planned. See H. Con. Res. 393-100th Congress (1987-1988), available at http://www.congress. gov/bill/100th-congress/house-concurrent-resolution/393.

13 Supra note 6. 
to China the importance of treaty obligations under the Joint Declaration $1984 .{ }^{14}$

A breakthrough was made in 1992, however. On September 20, 1992, Senator Mitch McConnell (R-KY) introduced the bill of Hong Kong Policy Act. On October 5, the Hong Kong Act 1992 became a law under Chapter 66 of Title 22 "Foreign Relations and Intercourse" of the US Code. ${ }^{15}$ The Hong Kong Act 1992 is the first framework legislation for the US to handle its relations with Hong Kong.

\section{B. Content}

The Hong Kong Act 1992 consists of four main parts. First, the Act, in "Findings and Declarations," introduces the background and aspirations. The US recognized Hong Kong's important role in regional and global economy, which was partly reflected in its close ties with the US. The US recognized and supported for what had been reached in the Joint Declaration 1984 and hoped to fully implement its contents. However, it should be noted that the US mentioned much about China's commitments, while little about China's sovereignty over Hong Kong. Furthermore, the Hong Kong Act 1992 supports the democratization in Hong Kong. In particular, the Act appears to respect human rights in Hong Kong, which, in the view of the US, are "of great importance to the United States and directly relevant to the US's interests in Hong Kong” and "a basis for Hong Kong's continued economic prosperity."16

Second, the Hong Kong Act 1992 regulates Hong Kong's general bilateral relations, international organizations, treaties, commerce, transportation and cultural and education exchanges. The themes of these arrangements are to maintain and expand contacts in political, economic, trade, financial, monetary, aviation, shipping, communications, tourism, cultural, sport, and other appropriate areas. For instance, the US was committed to fulfilling its obligations to Hong Kong under international agreements, "regardless of whether the People's Republic of China is a party to the particular international agreement." 17 Furthermore, the US should continue to (a) treat Hong Kong as a separate territory in economic and trade matters; (b) negotiate directly with Hong Kong to conclude bilateral economic agreements; (c) support access by Hong Kong to sensitive technologies controlled under the agreement of the Coordinating Committee for Multilateral Export Controls, if the US is satisfied that such technologies are protected from improper use or export. The US should

\footnotetext{
4 Y. Guo, Historical Investigation of American Congress Interference in Hong Kong Affairs [美国国会干涉中国香港事 务的历史考察], 22(2) ConTEMP. CHINA Hist. [当代中国史研究] 103-4 (2015).

15 Public Law No. 102-383, available at https://www.congress.gov/bill/102nd-congress/senate-bill/1731/text.

16 Hong Kong Act 1992 § 2.

17 Id. $\$ 102(2)$.
} 
also recognize certificates of origin for manufactured goods issued by the SAR and negotiate a bilateral investment treaty with Hong Kong. ${ }^{18}$ In addition, "the laws of the United States" shall continue to apply to Hong Kong. ${ }^{19}$

Third, the Hong Kong Act 1992 includes the reporting requirements. The US Secretary of State is required to forward the reports on conditions in Hong Kong to the House and Senate. The reports should, among others, include significant developments in US's relations with Hong Kong, changes in the exercise of sovereignty over Hong Kong which affects the US's interests in Hong Kong or the US's relations with Hong Kong, the development of democratic institutions in Hong Kong, and any determination made by the President. ${ }^{20}$ In addition, other state reports should include a separate subpart for Hong Kong. ${ }^{21}$

Fourth, the Hong Kong Act 1992 provides the suspension and termination of relations with or treatment to Hong Kong. After considering "the terms, obligations, and expectations" expressed in the Joint Declaration 1984, ${ }^{22}$ the President may issue an Executive Order suspending the US laws' application to Hong Kong if s/he determines that Hong Kong "is not sufficiently autonomous to justify treatment under a particular law of the United States, or any provision thereof, different from that accorded the People's Republic of China. ${ }^{, 23}$ This implies the US has great discretion in making such a determination which can be based on not only definite commitments China has made, but also general willingness China has shown through both the Joint Declaration 1984 and the US laws.

Such an Executive Order may be surely terminated when Hong Kong "has regained sufficient autonomy to justify different treatment under the law or provision of law in question.. ${ }^{24}$ Furthermore, the obligations of the US under international treaties against Hong Kong can also be modified or terminated "in accordance with law. ${ }^{25}$

On October 11, 1992, the Chinese government issued a serious protest to the US. China argued that the US, by enacting the Hong Kong Act 1992, intervened in Hong Kong affairs and China's domestic affairs, and infringed well-recognized

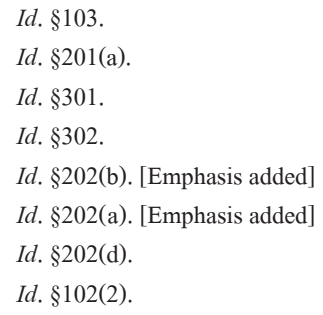


international norms. Therefore, that Act was "unacceptable to China." ${ }^{26}$ Chinese observers hold a similar view. ${ }^{27}$

As noted above, however, the keynote of the Hong Kong Act 1992 is to maintain and enhance the exchanges with Hong Kong. Especially, the Hong Kong Act 1992 provides the legal basis and framework for maintaining treatment and privileges to Hong Kong which is not available to the rest of China but surely helpful to China. Arguably, the Hong Kong Act 1992 implied a belief prevailing in the American society that the US can maintain Hong Kong and further include China into the liberal international order led by the US. ${ }^{28}$

Furthermore, the Hong Kong Act 1992 arguably blocked several initiatives in the US Congress aiming to express the US's stronger position towards Hong Kong affairs. For instance, an initiative to adopt Hong Kong Reversion Act was debated in the Congress in 1996 and $1997,{ }^{29}$ but finally failed.

\section{Implementation}

Among efforts that the US took to enforce the Hong Kong Act 1992, the most important one is that the US maintained effective treaties with the UK regarding Hong Kong. Before Hong Kong's return to China, the US had approximately nineteen bilateral agreements with Hong Kong, many of which were concluded with the UK but were 'extended' to Hong Kong. ${ }^{30}$ With the exception of defense agreements, most of these agreements, after consultation with the Chinese government, continued to apply after 1997. ${ }^{31}$ Furthermore, the US concluded several new treaties with Hong Kong. For instance, on March 25, 2014, the US signed the tax information exchange agreement ("TIEA") with Hong Kong, which is the first TIEA for Hong Kong Part. ${ }^{32}$

The reports for the Hong Kong Act 1992 addressed opposite positions from the Chinese government without exception. However, most of reports, such as the report

26 PRC, 31 State Council Gaz. 1338 (1992)1353.

27 J. Zhang \& Z. Zhang, Intervention of the U.S. Congress in Hong Kong Affairs and Its Implication [香港回归以来美国 国会对香港事务的介入及其影响], 25(7) PAC. J. [太平洋学报] 26-7 (2017). See also supra note 14, at 105.

28 Ikenberry, on debate on the rise of China, was optimistic that "Today's Western order, in short, is hard to overturn and easy to join." See J. Feinerman, Chinese Participation in the International Legal Order: Rogue Elephant or Team Player?, CHINA Q. 196-210 (1995).

29 Hong Kong Reversion Act, H.R. 750 (105th), available at https://www.govtrack.us/congress/bills/105/hr750/text.

30 Supra note 13 , at 352 .

31 Id. at 353-4.

32 HKSAR, Hong Kong and US sign tax information agreement, Press Release (Mar. 25, 2014), available at https:// www.info.gov.hk/gia/general/201403/25/P201403250452.htm. 
of 2003, have given quite a positive evaluation. ${ }^{33}$

Be that as it may, the US's evaluation on Hong Kong situation tends to be more negative in recent. For instance, in the latest report issued on March 21, 2019, the US asserted that "policies and practices of the Chinese Central Government have adversely impacted Hong Kong in multiple areas and constrained Hong Kong's political space, and Hong Kong authorities took actions in support for the Central Government at the expense of human rights and fundamental freedoms, such as democratic electoral processes, freedom of expression, and freedom of association."34 Although the Report of 2019 indicates that the US has not made suspension, termination or determination of its treaties with Hong Kong in accordance with the Hong Kong Act 1992, ${ }^{35}$ there were strong protests from China. ${ }^{36}$

\section{Hong Kong Human Rights and Democracy Act of 2019}

\section{A. Background}

The Hong Kong Democracy Act 2019 was caused by the escalating political protection and riots in Hong Kong. More directly, however, it was triggered by an extradition bill in relation to Mainland China. In February 2019, the SAR proposed the bill of the Fugitive Offenders and Mutual Legal Assistance in Criminal Matters Legislation (Amendment) (hereinafter 2019). ${ }^{37}$ This bill aims to amend the Fugitive Offenders Ordinance. While the Fugitive Offenders Ordinance authorizes the Hong Kong SAR to establish mutual legal assistance in criminal legal matters with any place outside Hong Kong, excluding Mainland China, Macau SAR and Taiwan. ${ }^{38}$

As mentioned above, the 2019 Bill was proposed by an extradition case. When a young Hong Kong man killed his girlfriend in Taiwan and fled back to Hong Kong, it

33 US Dept. of State, US Hong Kong Policy Act Report, available at https://2001-2009.state.gov/p/eap/rls/rpt/19562. htm.

34 US Dept. of State, 2019 Hong Kong Policy Act Report, available at https://www.state.gov/2019-hong-kongpolicy-act-report.

35 Id.

36 G. Shuang (Foreign Ministry Spokesperson), Regular Press Conference, PRC Ministry of Foreign Affairs (Mar. 22,

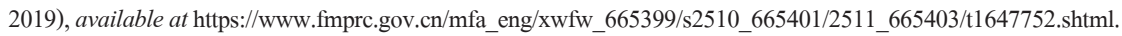

37 Fugitive Offenders and Mutual Legal Assistance in Criminal Matters Legislation (Amendment) Bill 2019, available at https://www.legco.gov.hk/yr18-19/english/bills/b201903291.pdf.

$38 \quad$ Id. $\$ 2$. 
raised a serious concern as to how to punish such murder crime. ${ }^{39}$ Under the current Fugitive Offenders Ordinance, the suspect could not be extradited to Taiwan for trial. The 2019 Bill aims to fill the gap in the Fugitive Offenders Ordinance as to the cooperation on criminal matters between Hong Kong and the rest of China (including the Mainland). "A place outside Hong Kong” in the 2019 Bill, which may reach arrangements in criminal matters, does not exclude the Mainland China, together with Macau SAR and Taiwan. ${ }^{40}$ It paves the way for arrangement in criminal matters between Hong Kong and Mainland China, including the extradition of criminal suspects to the Mainland. Given low confidence prevailing among the public in Hong Kong on the judicial system in the Mainland and presumably great worries that some laws in the Mainland, via the amendment of Fugitive Offenders Ordinance, would be de facto applied in Hong Kong, protests started in mid-2019. Protesters further required the so-called "Five demands," ${ }^{, 11}$ which especially include the "dual universal suffrage" in the production of Legislative Council and the Chief Executive of the Hong Kong SAR. ${ }^{42}$ Obviously, "Five demands" go beyond the initial purpose of protests and are rejected by the Hong Kong SAR Government. Protests escalated with widespread violence and riots. On October 23, 2019 the Hong Kong SAR Government withdrew the Bill from the Legislative Council, but such a compromise did not stop protests. The protests and riots have weakened, but are still continuing.

The protests and riots in Hong Kong draw wide international attention, especially the US. For many American politicians, the Hong Kong SAR Government abuses the human rights in the enforcement against the protests and, more generally, derogates the Joint Declaration 1984 and the Basic Law 1990. Furthermore, the US asserted that the Central Government does not honor the commitment of "One Country, Two Systems" provided in the both legal instruments, violating human rights in Hong Kong. Actually, the US government, directly or indirectly, was involved in the protests in Hong Kong by financial and diplomatic supports. ${ }^{43}$

Against this backdrop, on June 13, 2019, the bill of Hong Kong Human Rights and

39 A. Gunia, Taiwan Asks Hong Kong for Return of the Murder Suspect Whose Case Sparked Months of Protests, YAHOO NEws, Oct. 22, 2019, available at https://news.yahoo.com/hong-kong-taiwan-clashing-over-092132030.html.

40 The 2019 Bill, §3(3)(a).

41 W. Tsui-kai, Hong Kong protests: What are the 'five demands'? What do protesters want?, S. ChInA Morning Post, Aug. 20, 2019, available at https://www.scmp.com/yp/discover/news/hong-kong/article/3065950/hong-kong-protestswhat-are-five-demands-what-do. ("Five demands" mean that for the protests not to be characterized as a 'riot,' amnesty for arrested protesters, an independent inquiry into alleged police brutality, implementation of complete universal suffrage, the withdrawal of the bill.).

42 Id.

43 T. Cartalucci, US Is Behind Hong Kong Protests Says US Policymaker, Global Res. (Sept. 10, 2019), available at https://www.globalresearch.ca/us-behind-hong-kong-protests-says-us-policymaker/5688690. 
Democracy Act of 2019 was introduced in the House and the Senate, respectively. On October 15, the House unanimously passed the bill. Then, on November 19, the bill was also approved by the Senate with minor revisions. The revised bill was immediately accepted by the House and then sent to President Trump for signature. On November 27, President Trump signed the Hong Kong Democracy Act. ${ }^{44}$

Furthermore, current China-US confrontation may be a legislative background for the Hong Kong Democracy Act 2019. The US significantly reoriented its China policy after Trump took presidency in 2016. The US, in its National Security Report of 2017, identified China as a "revisionist power" for the first time. ${ }^{45}$ The US asserted that China tries to seek to "challenge American power, influence, and interests, and attempt to erode American security and prosperity" and to "shape a world antithetical to U.S. values and interests." "Therefore, the US has taken various containments against China in a large areas, such as the initiation of trade war with China and the imposition of rigid sanctions against Chinese technical corporations like Huawei. The Hong Kong Democracy Act 2019 is arguably one of tools for the US to fast restrict rising China in addition to the Sino-US Trade War. ${ }^{47}$

\section{B. Content}

The Hong Kong Democracy Act 2019 is an advanced and amended version of the Hong Kong Act 1992. It contains several new provisions.

First, the US, in the new law, redesigned its basic Hong Kong policy as well as its China policy. In contrast with the Hong Kong Act 1992 which ostensibly seeks to balance different policy purposes, the new law, as suggested by its title, clearly focuses on the political dimension. The Hong Kong Democracy Act 2019 hardly mentions such policies as enhancing ties with Hong Kong as the Hong Kong Act 1992. Instead, it states that Hong Kong "must retain sufficiently autonomous" from China to "justify treatment under a particular law of the United States, or any provision thereof, different from that" accorded to China. ${ }^{48}$ Importantly, the new law includes several aggressive policy purposes directly targeted against China.

44 H.R.3289- Hong Kong Human Rights and Democracy Act of 2019, available at https://www.congress.gov/bill/116thcongress/house-bill/3289/all-actions?overview=closed\&KWICView=false.

45 The White House, National Security Report of the United States 25 (Dec. 2017), available at https://www. whitehouse.gov/wp-content/uploads/2017/12/NSS-Final-12-18-2017-0905.pdf.

46 Id. at 2. See also J. Mearsheimer, The Tragedy of Great Power Politics 401- 2 (2001).

47 See A Double-edged Sword at Trump's Negotiating Table: the Hong Kong Human Rights and Democracy Act of 2019 [特朗普談判桌上的「雙刃劍」:香港人權法案], BBC NEws, Nov. 11, 2019, available at https://www.bbc.com/ zhongwen/trad/world-50486794.

48 Hong Kong Democracy Act 2019, §3. 
For instance, the US explicitly 'urge[s]' China to honor its commitments to Hong Kong and 'support[s]' the democratic aspiration of Hong Kong people. ${ }^{49}$ The Hong Kong Democracy Act 2019 states that the US will draw international attention to any violation of China's government of fundamental human rights of Hong Kong people and any encroachment on the autonomy guaranteed to Hong Kong. ${ }^{50}$ Thus, the new law requires Secretary of State, when granting visa for travel and work in the US, to take any activities against Chinse journalists affiliated with any Chinese "statecontrolled media" which are involved in the disinformation or intimidation and threatening of "perceived enemies" in Hong Kong and other countries. ${ }^{51}$ The Hong Kong Democracy Act 2019 also provides that the US will "coordinate with allies" to promote democracy and human rights in Hong Kong. ${ }^{52}$ Clearly, in contrast with the Hong Kong Act 1992, the Chinese government is a major target of the Hong Kong Democracy Act 2019. Therefore, the new law represents not only the US's Hong Kong policy but also its China policy.

Second, the Hong Kong Democracy Act 2019 includes new provisions aimed to protect the US's interests in Hong Kong. For instance, the new law strengthens the surveillance over the potential violations of the US Export Control Law in Hong Kong and the role of the Chinese government in the potential violations. In particular, the new law requires to assess the role in such potential violations of Hong Kong as a part of "Great Bay Area plan," "a national technology and innovation center," or a participant in "other program that [China] may exploit Hong Kong as a conduit for controlled sensitive technology." ${ }^{, 53}$ The new law also requires a close examination on the potential legislation in Hong Kong which will make it likely to extradite American citizens to Mainland China. $^{54}$

Third, the new law includes provisions arguably in support for "democracy and human rights" in Hong Kong. For instance, the visa applications of those who "have been formally charged, detained, or convicted" in Hong Kong SAR, Macau SAR and Mainland China for their political activities may not be denied. For this purpose, the US Consulate in Hong Kong is required to maintain a list of such persons and all consular officers should receive special training to carry out this policy. ${ }^{55}$ However,

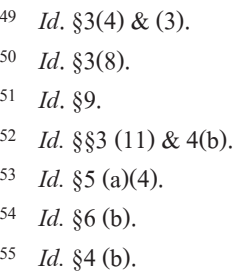


it strengthens the existing provisions and includes new provisions having little to do with democracy and human rights including, for instance, the provision of export control, the UN sanction enforcement, and Hong Kong's more integration in Mainland China by participating in "Great Bay Area plan," etc.

Fourth, the Hong Kong Democracy Act 2019 includes a section entitled "sanctions related to undermining fundamental freedoms and autonomy in Hong Kong." Under the new law, the US should impose sanction on those found to be responsible for "(A) the extrajudicial rendition, arbitrary detention, or torture of any person in Hong Kong; or (B) other gross violations of internationally recognized human rights in Hong Kong. ${ }^{, 58}$ Interestingly, those subject to the US sanctions are clearly narrower than those who may be targeted in accordance with the title of Section 7 . The possible sanctions include asset blocking, ineligibility for visas, admission, or parole to the US, and penalties. ${ }^{59}$ However, such a sanction may be waivered or terminated if it is "in the national interest of the United States." ${ }^{60}$ Moreover, it should be also noted that the provision of sanction is a 'sunset' provision. Thus, it, together with sanctions imposed on in accordance with it, shall terminate five years after the date of entry into force of the new law. ${ }^{61}$

For some time, most analysts appear to share a consensus that the Hong Kong Democracy Act 2019, albeit significant, is symbolic. They are of view that huge political and economic interests of the US in Hong Kong may discourage the Act to be really enforced in the future. ${ }^{62}$ The Hong Kong SAR, in commenting on the Act, noted that the US "has enormous economic interests in Hong Kong, including earning from Hong Kong, the largest bilateral trade surplus among her global trading partners for the past decade, and the surplus stood at over USD 33 billion last year" and thus it warned that "[A]ny unilateral change of US economic and trade policy towards Hong Kong would create a negative impact on the relations between the two sides as well as the US's own interests." ${ }^{\circ 3}$ People may also have a similar sense from the loose

56 Id. \$5 (a)-(c). See also Outline of the Guangdong-Hong Kong-Macau Greater Bay Area Development Plan, XINHUA News, Feb. 18, 2019, available at http://www.gov.cn/zhengce/2019-02/18/content_5366593.htm\#1.

$57 \quad$ Id. $\$ 7(\mathrm{a})-(\mathrm{h})$.

$58 \quad$ Id. $\$ 7$ (a) (1) \& (b).

$59 \quad I d . \S 7(\mathrm{c})$.

$60 \quad I d . \S 7(\mathrm{e}) \&(\mathrm{f})$.

$61 \quad I d . \$ 7(\mathrm{~h})$.

62 Y. Lee, US law backing Hong Kong protests could end up hurting everyone - the US, CNBC, Nov. 28, 2019, available at https://www.cnbc.com/2019/11/29/what-trump-bills-on-hong-kong-rights-protections-means-for-china-hk-and-us. html.

63 Supra note 4. 
provision of sanctions in the Hong Kong Democracy Act 2019. This position can also arguably be found in the statement of Trump Administration. President Trump, upon his signing the new law, stated that certain provisions of the Hong Kong Democracy Act 2019 would "interfere with the exercise of the President's constitutional authority to state the foreign policy of the United States."64 This implies that the Trump Administration may not apply the Act as it is expected by the Congress.

Nevertheless, if considering the largest trade war initiated by the US against China in 2018, which is obviously beyond the imagination of many observers, the Hong Kong Democracy Act 2019 would have something more in the future.

Presumably, several considerable negative impacts will emerge over time. First, the new law might chill the Hong Kong SAR government. For instance, the SAR Government may be discouraged to push national security legislation. In the view of the Central Government in Beijing, Hong Kong has the obligation under the Basic Law to enact in national security, which is of significance for China's national security. Given the widespread worries that such legislation would substantially damage the autonomy of Hong Kong, the SAR Government was forced to withdraw its legislation initiative which led to widespread protests. ${ }^{65}$ Second, the amendment of the Fugitive Offenders Ordinance appears dim in the following years. This increases the difficulty for China to fully exercise sovereignty over Hong Kong in accordance with the Basic Law 1990. Third, the US would possibly announce that Hong Kong loses the autonomy, regardless of the Joint Declaration 1984 and the Basic Law 1990. Thus, Hong Kong is no longer eligible to treatment or privileges that the US currently grants. Such a determination has a negative impact on Hong Kong, even though the US will not decide to suspend or terminate treatments or privileges available to Hong Kong or threaten to do so. Finally, the new law casts a shadow on the efforts to revitalize Hong Kong by participating in, for instance, the Great Bay Area plan.

\section{Conclusion}

Hong Kong, compared with other regions of China, occupies greater importance in China-US relations due to its special strategic arrangement as a global economic

64 Supra note 1.

65 T. Kellogg, Legislating Rights: Basic Law Article 23, National Security, and Human Rights in Hong Kong, 17 Colum. J. Asian L. 307 (2004). See also, A. Chen, How Hong Kong Law Will Change When Article 23 of the Basic Law is Implemented, 33 Hong Kong L. J. 1-7 (2003). 
center. Therefore, the US's Hong Kong policy should be assessed in a larger context of China-US relations. Judging from the Sino-US debate over Hong Kong, China insists more on "One Country" for national unity, while the US emphasizes on "Two Systems" to allow Hong Kong to maintain the economic freedom and the independent governance in tariff and justice. Essentially, the American concern lies in not only its national interests in Hong Kong, but also Sino-US relations entirely. Therefore, the US adopted various legal documents related to Hong Kong. The Hong Kong Act 1992 has been a legal leverage for the US's Hong Kong policy since 1997. In spite of dissatisfaction from the Chinese government, the US has established a quite friendly Hong Kong policy. It is much helpful to not only maintain and enhance the international status of Hong Kong as a trade, investment, financial center, but also facilitate China's engagement with the US-led global network of liberal democracy. In conclusion, Implicit in such a friendly Hong Kong policy obviously might be an expectation of the US that China would be included in so-called free world over time.

In contrast, the Hong Kong Democracy Act 2019 marks a negative change of the US's Hong Kong policy and, more importantly, of US's China policy as a whole. At a glance, the US, especially Congress, expresses the support for democracy and human rights in Hong Kong. However, the US seeks to discourage China to exercise sovereignty over Hong Kong and further to contain a rising China. This may explain why the new law ostensibly concerns the democracy and human rights in Hong Kong, but it includes several elements that have little to do with it. Therefore, although many observers assume that the new law may not make a difference in practice, the future development should be closely scrutinized. 